\title{
PELUANG DAN TANTANGAN KOMPETENSI PERADILAN AGAMA PASCA AMANDEMEN UNDANG-UNDANG NOMOR 7 TAHUN 1989 TENTANG PERADILAN AGAMA
}

\author{
Abu Tolhah \\ Mahkamah Agung Republik Indonesia \\ Email: abutolhah@yahoo.com
}

\begin{abstract}
The development of religious court in Indonesia is existing while the establishment of Islamic law as part of national law system. It is influenced by the improvement of legal thought which is the background of Islamic law legislation. In independence period, exactli on 1970, the government emphasizes the existence of religious court through the law of court institution number 14 of 1970. On 1977, Indonesian Supreme Court pusblished the rule of Islamic court through the law number 7 of 1989 in which give the religious court for casation to supreme court.
\end{abstract}

\begin{abstract}
Abstrak
Perkembangan Peradilan Agama di Indonesia terus berkembang seiring dengan perkembangan hukum Islam menjadi hukum nasional yang dipengaruhi oleh perkembangan pemikiran hukum yang mendasari proses legislasi berlakunya hukum Islam. Memasuki fase kemerdekaan, tepatnya pada tahun 1970, pemerintah lebih mempertegas keberadaan Pengadilan Agama dengan dikeluarkannya Undang-Undang Nomor 14 Tahun 1970 tentang Ketentuan-Ketentuan Pokok Kekuasaan Kehakiman. Pada tahun 1977 Mahkamah Agung mengeluarkan peraturan yang memperkuat bagi kedudukan Pengadilan Agama yang diatur dalam Undang-Undang Nomor 7 Tahun 1989 tentang Peradilan Agama, yaitu dengan diberikannya kewenangan bagi Pengadilan Agama untuk mengajukan kasasi ke Mahkamah Agung.
\end{abstract}

Kata Kunci:

Budaya Masyarakat, Hukum, Peluang dan Tantangan, Peradilan Agama

\section{A. Pendahuluan}

Kompetensi Peradilan Agama hingga saat ini tampaknya tidak bisa dilepaskan dari proses sejarah penyelesaian sengketa atau perkara yang muncul di kalangan masyarakat muslim di Indonesia. Selain itu, keberadaan Peradilan Agama tampaknya juga sangat erat kaitannya dengan dinamika perubahan politik hukum yang berlangsung sejak fase awal perkembangan Islam, fase penjajahan, hingga fase kemerdekaan Indonesia.' Salah

Hukum Islam di Indonesia berkembang sejalan dengan perkembangan dan perluasan wilayah Islam serta berhubungan dengan budaya dan masyarakatnya. Islam tumbuh di masyarakat menjadi sistem nilai dan menggeser norma-norma yang berlaku sebelumnya. Lihat Juhaya S. Praja, Hukum Islam di Indonesia (Bandung: Rosda Karya. 1981), hlm. I dan Anwar Haryono, Hukum Islam: Kekuasaan dan Keadilan (Jakarta: Bulan Bintang. 1968), hlm. 66-67. satu indikator penting yang mendukung asumsi di atas adalah menyangkut dinamika kompetensi Peradilan Agama yang kewenangannya diperluas sebagaimana diatur dalam Undang-Undang Nomor 3 Tahun 2006 tentang Perubahan Kedua atas UndangUndang Nomor 7 Tahun 1989 tentang Peradilan Agama.

Perkembangan Peradilan Agama di Indonesia terus berkembang seiring dengan perkembangan hukum Islam menjadi hukum nasional dipengaruhi oleh perkembangan pemikiran hukum yang mendasari proses legislasi berlakunya hukum Islam. Masa kolonial Belanda, muncul teori receptie in complexue yang pada hakikatnya mengakomodasikan hukum yang hidup di masyarakat. Kemudian untuk keperluan penjajahan Snouck Hugronje membuat teori receptie yang dikem- 
bangkan oleh Van Vollen Hoven, yaitu hukum Islam yang berlaku bagi masyarakat pribumi kalau norma hukum Islam itu telah diterima oleh masyarakat sebagai hukum adat.

Memasuki fase kemerdekaan, tepatnya pada tahun 1970, pemerintah lebih mempertegas keberadaan Pengadilan Agama dengan dikeluarkannya Undang-Undang Nomor 14 Tahun 1970 tentang Ketentuan-Ketentuan Pokok Kekuasaan Kehakiman. Dalam Pasal 10 disebutkan ada empat lingkungan peradilan di Indonesia, yaitu Peradilan Umum, Peradilan Agama, Peradilan Militer, dan Peradilan Tata Usaha Negara. Seluruh pengadilan tersebut disejajarkan posisinya secara hukum dan seluruh proses peradilan berpuncak kepada Mahkamah Agung. Dengan adanya Undang-Undang Nomor 14 Tahun 1970 ini, maka kekuatan Peradilan Agama sama dengan pengadilan-pengadilan lainnya yang ada di wilayah yurisdiksi Indonesia. Pada tahun 1977 Mahkamah Agung mengeluarkan peraturan yang memperkuat bagi kedudukan Pengadilan Agama yang diatur dalam Undang-Undang Nomor 7 Tahun 1989 tentang Peradilan Agama, yaitu dengan diberikannya kewenangan bagi Pengadilan Agama untuk mengajukan kasasi ke Mahkamah Agung.

\section{B. Selayang Pandang Kompetensi Per- adilan Agama}

Perkembangan Peradilan Agama di Indonesia terus berkembang seiring dengan perkembangan hukum Islam menjadi hukum nasional dipengaruhi oleh perkembangan pemikiran hukum yang mendasari proses legislasi berlakunya hukum Islam. Masa kolonial Belanda, muncul teori receptie in complexue yang pada hakikatnya mengakomodasikan hukum yang hidup di masyarakat. Kemudian untuk keperluan penjajahan Snouck Hugronje membuat teori receptie yang dikembangkan oleh Van Vollen Hoven, yaitu hukum Islam yang berlaku bagi masyarakat pribumi kalau norma hukum Islam itu telah diterima oleh masyarakat sebagai hukum adat. ${ }^{2}$

Setelah Indonesia merdeka, Hazairin berpendapat bahwa semua peraturan per-

2 Ichtiyanto, Pengembangan Teori Berlakunya Hukum Islam di Indonesia (Bandung: Rosda Karya. 1991), hlm. 100. undang-undangan Hindia Belanda yang berdasarkan teori receptie tidak berlaku lagi, karena bertentangan dengan jiwa UUD 1945 serta al-Quran dan Sunnah. Dengan demikian teori receptie itu harus exit alias ke luar dari tata hukum Indonesia merdeka. Maka berkembanglah teori receptie exit dalam sistem hukum Nasional.

Pengembangan teori receptie exit yang dikembangkan oleh Sayuti Thalib, selanjutnya adalah teori receptie a contrario yang secara harfiah berarti lawan dari teori receptie. Kalau teori receptie mendahulukan berlakunya hukum Adat daripada hukum Islam, dan hukum Islam tidak dapat diberlakukan bila bertentangan dengan hukum adat. Sedangkan teori receptie a contrario, mendahulukan hukum Islam daripada hukum Adat dan hukum Adat tidak diberlakukan bila bertentangan dengan hukum Islam. ${ }^{3}$

Memasuki fase kemerdekaan, tepatnya pada tahun 1970, pemerintah lebih mempertegas keberadaan Pengadilan Agama dengan dikeluarkannya Undang-Undang Nomor 14 Tahun 1970 tentang Ketentuan-Ketentuan Pokok Kekuasaan Kehakiman. Dalam Pasal 10 disebutkan ada empat lingkungan peradilan di Indonesia, yaitu Peradilan Umum, Peradilan Agama, Peradilan Militer, dan Peradilan Tata Usaha Negara. Seluruh pengadilan tersebut disejajarkan posisinya secara hukum dan seluruh proses peradilan berpuncak kepada Mahkamah Agung. Dengan adanya Undang-Undang Nomor 14 Tahun 1970 ini, maka kekuatan Peradilan Agama sama dengan pengadilan-pengadilan lainnya yang ada di wilayah yurisdiksi Indonesia. Pada tahun 1977 Mahkamah Agung mengeluarkan peraturan yang memperkuat bagi kedudukan Pengadilan Agama yang diatur dalam Undang-Undang Nomor 7 Tahun 1989 tentang Peradilan Agama, yaitu dengan diberikannya kewenangan bagi Pengadilan Aga-

3 Dalam pandangan Sayuti Thalib, jika hukum Islam telah masuk dan tereceptie (diterima) dalam hukum Adat adalah paradigma yang keliru. la beralasan bahwa hukum Islam maupun hukum Adat keduanya merupakan hukum yang mandiri. Atas dasar itu, Hazairin menyebut teori van Vollen Hoeven sebagai "teori iblis" karena bertentangan dengan hukum Islam. Mura P Hutagalung, Hukum Islam dalam Era Pembangunan (Jakarta : In Hill Co. 1985), hlm. 19-20. 
ma untuk mengajukan kasasi ke Mahkamah Agung. ${ }^{4}$

Namun demikian, pada kenyataannya Pengadilan Agama masih memerlukan pengakuan dan pengesahan dari Pengadilan Negeri, bahkan Pengadilan Negeri dapat meninjau keputusan Pengadilan Agama tersebut. Sekalipun pada tahun 1974 dikeluarkan Undang-Undang Nomor 1 Tahun 1974 tentang Perkawinan, yang juga mengatur yurisdiksi Pengadilan Agama, seluruh keputusan Pengadilan Agama tetap harus mendapatkan dan/atau meminta pengukuhan eksekusi (executoir verklaaring) dari Pengadilan $\mathrm{Ne}$ geri. Hal ini dapat dinyatakan bahwa keputusan Pengadilan Agama berada di bawah Pengadilan Negeri.

Pasca runtuhnya Orde Baru, perkembangan Peradilan Agama mengalami perubahan signifikan yakni ditandai dengan lahirnya Undang-Undang Nomor 35 Tahun 1999 sebagai perubahan atas Pasal 2 dari UndangUndang Nomor 14 Tahun 1970 tentang Ketentuan-Ketentuan Pokok Kekuasaan Kehakiman. Undang-Undang Nomor 35 Tahun 1999 tentang Perubahan atas UndangUndang Nomor 14 Tahun 1970 menentukan sebagai berikut:

Pertama, badan-badan Peradilan Agama secara organisatoris, administratif, dan finansial berada di bawah kekuasaan Mahkamah Agung. Ini berarti kekuasaan Departemen Agama terhadap Peradilan Agama dalam bidang-bidang tersebut, yang sudah berjalan

4 Perubahan dari segi nama dilakukan pemerintah pada tahun 1980 melalui keputusan Menteri Agama No. 6 Tahun 1980 Tanggal 28 Januari 1980 tentang penyeragaman nama lembaga menjadi sebutan Pengadilan Agama. Nama Pengadilan Agama yang beragam seperti Kerapatan Qadhi di Kalimantan, Mahkamah Syar'iyah di luar Jawa dan Madura, menjadi satu nama di seluruh Indonesia, yakni Pengadilan Agama. Kerapatan Qadhi Besar di Kalimantan Selatan dan Mahkamah Syar'iyah propinsi di luar Jawa dan Madura sebagai pengadilan banding, disebut Pengadilan Tinggi Agama. Selain nama dan letaknya yang seragam, di setiap kabupaten dan kotamadya tempat adanya Pengadilan Agama. Bersama-sama dengan keempat lingkungan peradilan, Peradilan agama, Pengadilan Tinggi Agama berpuncak pada Mahkamah Agung. Lihat Mohammad Daud Ali dan Habibah Daud, Lembaga-lembaga Islam di Indonesia (Jakarta: Rajawali Pers. 1995), hlm. 114. sejak proklamasi, akan beralih ke Mahkamah Agung;

Kedua, pengalihan organisasi, adiministrasi, dan finansial dari lingkungan Peradilan Negeri, Peradilan Militer, dan Peradilan Tata Usaha Negara ke Mahkamah Agung dan ketentuan pengalihan untuk masing-masing lingkungan peradilan diatur lebih lanjut dengan Undang-Undang sesuai dengan kekhususan lingkungan peradilan masing-masing serta dilaksanakan secara bertahap selambat-lambatnya selama lima tahun. Sedangkan bagi lingkungan Peradilan Agama waktunya tidak ditentukan; dan

Ketiga, ketentuan mengenai tata cara pengalihan secara bertahap tersebut ditetapkan dengan Keputusan Presiden Nomor 21 Tahun 2000.

Pada perkembangan selanjutnya, dilakukan perubahan politik hukum yang mengatur pemindahan institusi melalui kebijakan satu atap Pengadilan Agama menjadi di bawah Mahkamah Agung Republik Indonesia. Sehingga sejak tahun 2004, Pengadilan Agama secara administratif, organisatoris, dan pembinaan teknis berpindah dari Departemen Agama ke Mahkamah Agung sesuai amanat Undang-Undang Nomor 35 Tahun 1999, maka disahkanlah Undang-Undang Nomor 3 Tahun 2006 tentang Peradilan Agama yang berisi tentang penyatuatapan tersebut.

Adapun perkembangan politik hukum yang paling mutakhir adalah berkaitan dengan dinamika kompetensi Peradilan Agama yang kewenangannya diperluas sebagaimana diatur dalam Undang-Undang Nomor 3 Tahun 2006 tentang Perubahan atas Undang-Undang Nomor 7 Tahun 1989 tentang Peradilan Agama. Jika dalam Pasal 49 Undang-Undang Nomor 7 Tahun 1989 Peradilan Agama hanya berwenang menyelesaikan perkara perdata bagi orang Islam, maka dalam Pasal 49 Undang-Undang Nomor 3 Tahun 2006 kewenangan diperluas yakni berwenang pula untuk menyelesaikan sengketa ekonomi syari'ah.

\section{Proses Penguatan Institusi Peradilan Agama dalam Sistem Peradilan}

Konflik dan pengalaman yang terjadi dalam dinamika tumbuh dan berkembangnya 
Peradilan Agama di Indonesia, bermula dari datangnya penjajah Belanda yang mempunyai politik dagang (VOC) dan politik missionaris kristen. Pergulatan politik ini juga disebabkan oleh epistimologi hukum antara paham negara sekuler dan paham negara agama. Dalam konteks ini, ada tiga teori konflik untuk menganalisa hubungan agama dan negara. Pembahasan di sini akan dibatasi pada teori konflik Ralf Dahrendorf dengan teori Konflik Dialektiknya dan teori Fungsionalisme Konflik dari Lewis A. Coster, serta teori Struktural Fungsional dari Talcott Parsons.

Dahrendorf merupakan salah satu eksponen yang beranggapan bahwa masyarakat memiliki dua wajah (konflik dan konsensus). Baginya, masyarakat tidak mungkin ada tanpa keduanya (konflik dan konsensus). Kita tidak bisa konflik tanpa ada konsensus sebelumnya. Misalnya, hukum Islam tidak akan mengalami konflik dengan jenis hukum lain jika tidak ada konsensus bersama untuk membentuk negara (Indonesia). Sebaliknya, konflik dapat menyebabkan konsensus dan integrasi. Dari konflik yang pernah ada di antara berbagai pihak yang berkepentingan, maka lahirlah hukum nasional.

Achmad Gunaryo mengutip pendapat Parsons yang terkenal dengan teori struktural fungsionalisme, teori ini mengatakan bahwa setiap sistem aksi baik itu berupa masyarakat, lembaga, kelompok-kelompok kecil, dan lain-lain memiliki ciri-ciri umum, di mana di situ ada persyaratan fungsional yang harus dipenuhi. Persyaratan fungsional itu adalah 1) adaptasi; 2) pencapaian tujuan; 3) integrasi; dan 4) pemeliharaan pola. ${ }^{5}$

Parsons, dengan teori struktural fungsionalismenya, melihat bahwa sistem sosial itu memiliki struktur yang selalu mengarah pada stabilitas dan keseimbangan. Bagi Parsons, di dalam masyarakat ada suatu skema konseptual yang merefleksikan keterkaitan sistemik dari sistem sosial. Krusial terhadap konseptualisasi sistem sosial ini adalah institusionalisasi atau pelembagaan, yang merujuk pada pola-pola yang relatif stabil

5 Achmad Gunaryo, Pergumulan Politik dan Hukum Islam, Reposisi dari Peradilan "Pupuk Bawang" ke Peradilan sesungguhnya (Semarang, Pustaka Pelajar. 2007), cet. I. hlm. 36. dari interaksi di antara para aktor sosial. Pola-pola semacam itu secara normatif diatur dan diisi dengan pola budaya (cultural patterns). Parsons melihat pelembagaan sebagai proses sekaligus struktur.

Berbeda dengan Parsons, Ralf Dahrendorf, dengan teori konflik dialektikanya melihat bahwa setiap masyarakat dalam setiap jengkalnya selalu berada dalam konflik. Konflik disebabkan oleh tujuan yang berbeda-beda dari berbagai macam kelompok kepentingan dalam sistem sosial. ${ }^{6}$

Konflik tentang hukum dasar negara ini, bagi umat muslim Indonesia sudah sejalan dengan pendapat Ibnu Taymiyyah yang mengkritik paham sekulerisme (separation between state and religion) dengan mengatakan bahwa keadaan manusia akan rusak apabila antara agama dengan sultan masingmasing berdiri sendiri. ${ }^{7}$ Ratno Lukito, Hukum Sakral dan Hukum Sekuler, menyebutkan bahwa dengan filosofisch gronsdlag, Pancasila dapat dilihat sebagai dasar negara dan sekaligus merupakan fenomena pluralistis normatif dalam sistem hukum Indonesia yang dikaji dari perspektif sejarah perkembangan hukum. ${ }^{8}$

Pencoretan tujuh kata dalam pembukaan (preamble) dalam proses disahkannya Undang-Undang Dasar 1945 jelas merupakan solusi tengah yang mengakomodasi kelompok sekuler dan kelompok Islam sehingga keduanya bisa bekerja sama dan merupakan "win-win solution" dalam perdebatan panjang tentang hubungan negara dan agama. Akan tetapi, menurut Ratno Lukito menjelaskan untuk waktu lebih jauh ada dua persoalan yang masih mengganjal: pertama, sejauh mana penerimaan negara terhadap nilai agama yang tumbuh di masyarakat itu bisa diterima; dan kedua bagaimana mengakomodasikan nilai sebuah agama dalam aparatur negara ketika kepercayaan agama dan umat beragama yang juga menuntut hak yang sama. ${ }^{9}$

6 Ibid. hlm. 37.

7 'Abd al-Rahman 'Abd al-'Azîz al-Qasim, alIslâm wa Taqnîn al-Ahkâm (Riyadl: Jami‘ah Riyadl. 1977), hlm. 282.

8 Ratno Lukito, Hukum Sakral dan Hukum Sekuler (Jakarta: Pustaka Alpabet. 2008), cet. I, hlm. 15.

9 Ibid. hlm. 243. 
Dalam ushûl fiqh tentang konsep negara dan konsep khilafah ada dua pendekatan yakni: pendekatan formalistik yang cenderung mementingkan bentuk dari pada isi, yang pada gilirannya menampilkan konsep negara dan simbolisasi keagamaaan; dan pendekatan substantivistik yang cenderung menekankan isi dari pada bentuk. Oleh karena itu konsensus yang melahirkan Pancasila sebagai dasar negara merupakan bentuk metode ijma' yang diterapkan di Indonesia dengan mengambl kaidah ushûliyyah "alhukmu yadûru ma'a al-illat wujûdan wa "Adamân"10

Hal ini juga berdasarkan sebuah kaidah:

$$
\text { تغيرالفتوى بحسب تغيرالأزمنة والأمكنة والأحوال والنيات }
$$

Perubahan fatwa karena perubahan zaman, tempat, keadaan, niat, dan kebiasaan.

Konfik-konflik dan pengalaman sejarah Peradilan Agama dapat ditelusuri dengan menyingkap aturan-aturan atau landasan hukum yang memberi justifikasi keberadaannya. Sesuai dengan paham eksestensialisme Paul Tillich yang dikutip Oleh Titus dkk mengatakan bahwa Eksistensialisme sebagai unsur yang universal dalam segala pemikiran. Eksesitensialisme adalah usaha manusia untuk melukiskan eksitensinya serta konflikkonflik tersebut, asal mula konflik tersebut serta upaya untuk mengatasinya. ${ }^{12}$

Pendapat Paul Tillich dapat menjadi analisis tentang konflik-konflik yang terjadi:

1. Peradilan Agama telah tumbuh dan melembaga di bumi Nusantara ini, sejak Islam dianut oleh penduduk yang berada di wilayah ini berabad-abad sebelum kehadiran penjajah, karena kebutuhan dan

10 A Djazuli, Fiqh Siyasah: Implementasi Kemaslahatan Ummat dalam rambu-rambu Syari'ah (Jakarta: Kencana Prenada Media Group. 2003), cet. ke-3, hlm. 36.

11 Ibn Qayyim al-Jawziyyah, I'lam al-Muwaqqi'în 'an Rabb al'Âlamîn (Beirut: Dâr al-Fikr. t.th.), ditahqiq oleh 'Abd al-Rahman al-Wakil, juz III, hlm. 4.

12 Harold H.Titus, Marilyn S.Smith, Richard T. Nolan, Living Issues in Philoshophy, alih bahasa, H.M. Rasyidi, Persoalan-persoalan Filsafat (Jakarta: Bulan Bintang. 1984), hlm. 383. kesadaran hukum sesuai dengan keyakinan pada ajaran agama. Sebelum Peradilan Agama diresmikan pada tahun 1882, Pemerintah Kolonial telah mengetahui keberadaan dan berjalannya Peradilan Agama di Indonesia seperti adanya Instruksi Pemerintah Hindia Belanda pada bulan September 1808 kepada para Bupati di Jawa yang menegaskan bahwa urusan agama orang Jawa tidak akan diganggu dan pemuka agama mereka dibiarkan memutuskan perkara tertentu dalam bidang perkawinan dan kewarisan. Resolusi Gubernur Jenderal tanggal 3 Juni 1823 Nomor 12 tentang Peresmian Pengadilan Agama di kota Palembang, Ketetapan Komisaris Jenderal tanggal 12 Maret 1828 Nomor 17 yang menetapkan bahwa khusus untuk Jayakarta (Batavia) di tiap-tiap distrik dibentuk majelis distrik, Pemerintah Hindia Belanda mengeluarkan penjelasan tentang Pasal 13 Staatsblad 1820 Nomor 22, pada tahun 1864 melalui Pasal 78 Regeerings Reglement (RR) 1854 (Staatsblad 1855 Nomor 2) ditentukan batas kewenangan Peradilan Agama dan berbagai kebijaksanaan lainnya bagi peradilan Islam.

Pengalaman dan konflik pengebirian Peradilan Agama di atas, dikemukakan oleh Jan Frederick Gobius, sebagaimana dikutip oleh Mr. Tresna:

“....bahwa tidak disetujuinya campur tangan penghulu-penghulu dan pejabat kaum dalam proses peradilan di Priangan, dan juga sejak dikeluarkannya S.1847 No. 30, di Surakarta dan Jogyakarta para penghulu tidak diperbolehkan mengadili perkara-perkara yang dahulu menjadi kompetensi Pengadilan Surambi di zaman Sultan Agung".

Berdirinya Peradilan Agama di Jawa dan Madura pada tahun 1882, lebih disebabkan oleh adanya kesamaan pendapat di kalangan Pemerintah Kolonial Belanda sendiri bahwa hukum yang berlaku bagi masyarakat Indonesia adalah undangundang agama mereka yakni Hukum Islam, sesuai teori receptio in complexu dari Christiaan van den Berg.

Konflik dan timbulnya gangguan paling 
berarti dan efektif datang dari Christiaan Snouck Hurgronje (1857-1936), penasehat utama Pemerintah Hindia Belanda urusan Islam dan bumiputera, pada tahun 1898 mengkritik dan menentang pendapat van den Berg dengan teori Receptienya. Dengan teori Receptie, Christiaan Snouck Hurgronje mengatakan sebenarnya yang berlaku di Indonesia bukan hukum Islam, melainkan hukum Adat. Ke dalam hukum Adat itu memang masuk hukum Islam, tetapi hukum Islam baru mempunyai kekuatan dan dapat berlaku, jika sudah diterima sebagai hukum Adat.

Tujuan dari teori ini adalah untuk meredusir hukum Islam dengan berdalih mempertahankan masyarakat Adat. Usaha Sistematis ini berhasil melalui Pasal 134 ayat (2), Indische Staatsregeling (IS) yang berbunyi:

Dalam hal terjadi perkara perdata antara sesama orang Islam akan diselesaikan oleh Hakim Agama Islam apabila keadaan tersebut telah diterima oleh hukum Adat mereka dan sejauh tidak ditentukan oleh ordonantie. $^{13}$

Arti Pasal ini ialah bahwa hukum Islam yang berlaku hanyalah kalau telah diresepsi oleh Adat. Perubahan tersebut terjadi pada tahun 1929 melalui Staatsblad Nomor 211.

Atas dasar perubahan Pasal 134 ayat (2) I.S itu maka pada tahun 1937 kewenangan Pengadilan Agama di Jawa Madura dibatasi melalui Pasal 2 a Ordonantie Peradilan Agama di Jawa Madura (Staatsblad 1937 Nomor 116) yaitu hanya mengenai masalah perkawinan saja. Sedangkan perkara waris dicabut dan diserahkan pada Pengadilan Umum. Demikian pula di Kalimantan Selatan didirikan Kerapan Qadhi Kecil dan Kerapatan Qadhi Besar dengan Staatsblad 1937 Nomor 638 dan 639 yang wewenangnya seperti Pengadilan Agama Jawa dan Madura. Konflik ini dilhami juga oleh pendapat

13 Departemen Agama RI, Peradilan Agama di Indonesia: Sejarah Perkembangan Lembaga dan Proses Pembentukan Undang-Undangnya (Jakarta: Departemen Agama, Ditbinbapera. 2000), hlm. 14.
Nauta misalnya yang menyatakan bahwa masalah perkawinan dan warisan adalah masalah negara. Dalam tulisannya di koran Nieuwe Rotterdamssche Courant tanggal 27 Juli 1937 bahwa agama Islam boleh dianggap sebagai negara dalam negara (staat in den staat). ${ }^{14}$

2. Konflik berikutnya ketika pada tahun 1948, keluar Undang-undang Nomor 19 tentang Susunan dan Kekuasaan Badan Kehakiman dan Kejaksaan. Meski undangundang ini tidak sempat berlaku akan tetapi kewenangan Pengadilan Agama dimasukkan dalam Pengadilan Umum yang diatur dalam Pasal 35 ayat (2), Pasal 75 dan Pasal 33. Undang-undang ini merupakan peraturan yang penting tentang peradilan dalam masa pemerintahan RI Yogyakarta. Undang-undang ini bermaksud mengatur mengenai peradilan dan sekaligus mencabut serta menyempurnakan isi UU Nomor 7 Tahun 1947 tentang Susunan dan Kekuasaan Mahkamah Agung dan Kejaksaan yang mulai berlaku pada tanggal 3 Maret 1947.

Sehubungan dengan lingkungan peradilan, Undang-undang ini menetapkan tiga lingkungan peradilan, yaitu:

a) Peradilan Umum;

b) Peradilan Tata Usaha Negara; dan

c) Peradilan Ketentaraan. ${ }^{15}$

Selanjutnya melalui Undang-Undang Darurat No. I/Drt/1951 pemerintah secara tegas mempertahankan Peradilan Agama, untuk kemudian menghapus Peradilan Swapraja dan Peradilan Adat. Sebagai implementasi, pada tahun 1957 pemerintah mengatur pembentukan Peradilan Agama di luar Jawa-Madura dan Kalimantan Selatan melalui Peraturan Pemerintah Nomor 45 Tahun 1957.

3. Dalam rangka memenuhi Ketentuan Pasal 24 UUD 1945, pada Tahun 1964 keluarlah Undang-Undang Nomor 19 Tahun 1964 tentang Ketentuan-Ketentuan Pokok Kekuasaan Kehakiman yang kemudian diganti \& disempurnakan dengan UndangUndang Nomor 14 Tahun 1970. Dalam pro-

14 Ibid. hlm. 17.

15 Ibid. hlm. 21. 
ses pembahasan RUU tentang PokokPokok Kekuasaan Kehakiman ini, masalah Peradilan Agama menjadi lingkungan sendiri yang melaksanakan sebagian kekuasaan kehakiman telah dibahas secara mendalam dan mendapatkan protes khususnya ketentuan tentang adanya 4 lingkungan peradilan sebagaimana dalam Pasal 10 ayat (1).

Konflik-konflik perdebatan sengit tentang masuknya Peradilan Agama menjadi sebagaimana dikemukakan oleh Fraksi Partai MURBA melalui juru bicaranya Sahat $M$. Nainggolan menyampaikan pendapat bahwa: “.... hukum Adat dan hukum agama pada kenyataannya sama kuat dalam masyarakat, maka Peradilan Agama supaya diserahkan kepada LembagaLembaga Agama yang bersangkutan. Jadi bukan diatur oleh negara. Negara hanya sekedar memberikan bimbingan dan pengawasan. Dari segi teknis organisatoris, jika terlalu banyak macam peradilan, maka akan makin kacaulah peradilan". ${ }^{16}$

Fraksi Partai Katholik menyarankan agar peradilan hanya terdiri dari dua macam Peradilan yakni Peradilan Umum dan Peradilan Militer dengan kemampuan masing-masing mengadakan differensiasi secara limitatif dan berdasarkan asas efisiensi. ${ }^{17}$ Dan beberapa fraksi lainnya berpendapat bahwa adanya empat lingkungan Peradilan yang berbeda-beda dalam RUU tersebut dianggap sebagai kurang sejalan dengan prinsip equility before law. Adapun berkenaan dengan pandangan Fraksi-fraksi, Menteri Kehakiman, Oemar Senoadji, selaku wakil Pemerintah menyatakan: Prinsip equality before the law adalah merupakan salah satu hak asasi manusia di mana setiap orang berhak atasnya. Meskipun demikian, tidak akan mungkin serta tidak akan adil apabila prinsip ini akan diterapkan kepada semua warga negara tanpa pembedaan dan dalam semua perundang-undangan yang ada, sebab tanpa memperkecil arti dari prinsip equality before the law ini, per-

\footnotetext{
16 Ibid. hlm. 29.
}

17 Ibid. bedaan-perbedaan yang asasi yang ada di antara warga negara-warga negara kita yang bertalian dengan: usia, ras, jenis kelamin, jabatan, agama dan kondisi-kondisi lainnya, dapat dan seharusnya mendapatkan peraturan-peraturan yang berlainan dalam hukum. Bukanlah tiap legal distinction itu harus dipandang sebagai inequality before the law. Sebaliknya tidak dapat pula dikatakan bahwa asas inequality before the law itu hanya dianggap sah apabila factual conditions sama secara keseluruhan oleh karena itu selalu dapat dipikirkan suatu pengaturan hukum yang mengenai suatu golongan. ${ }^{18}$

4. Konflik yang terjadi saat pembahasan Rancangan Undang-Undang Peradilan Agama sejak disampaikan kepada DPR tanggal 28 Januari 1989 hingga hari pertama disahkan menjadi Undang-Undang Nomor 7 Tahun 1989 tentang Peradilan Agama, terdapat sekurang-kurangnya 400 tulisan pada media massa. Keadaan serupa terjadi tatakala kehadiran RUU Perkawinan yang disampaikan keterangan pemerintah di hadapan sidang pleno DPR tanggal 30 Agustus 1973. Suatu aktivitas legislatif yang menyentuh titik universal kehidupan rohani masyarakat, selalu merangsang timbulnya reaksi. ${ }^{19}$

Lebih lanjut Abdul Gani Abdullah memandang bahwa reaksi-reaksi atau konflikkonflik terjadi karena persoalan studi Peradilan Agama tidak hanya pada aspek institusional (pranatanya) saja, tetapi menyangkut aspek-aspek:

a) Filosofis ideologis yang menyingkap pandangan hidup dan kesadaran hukum;

b) Sistem hukum secara empirik mampu menunjukkan keragaman hukum positif;

c) Aspek sosio-antropologis menggambarkan hakim agama yang penegak hukum dan ulama di mata masyarakat;

d) Transformatif yang membentuk pan-

18 Ibid.

19 Abdul Gani Abdullah, Peradilan Agama dalam Wadah Negara Pancasila (Dialog tentang RUUPA) (Jakarta: PT. Logos Wacana Ilmu. 2001), hlm. xv. 
dangan dan kesadaran hukum masyarakat Islam baik melaui proses reintroduksi hukum Islam dengan mempertimbangkan kompleksita permasalahan masyarakat maupun distriusi kitab fiqih; dan

e) Fenomologis dimana lembaga Peradilan Agama dipandang sebagai sebuah gejala yang mampu mengungkap seluruh aspek tersebut. ${ }^{20}$

Adanya reformasi hukum, khususnya amandemen Undang-Undang Dasar 1945, Pasal 24 yang menyatakan bahwa Kekuasaan Kehakiman dilaksanakan oleh Mahkamah Agung dalam 4 lingkungan peradilan, menjadi dasar hukum yang kuat bahwa Pembangunan Sistem Hukum Nasional menuju arah terpisahnya kekuasaan kehakiman dari kekuasaan pemerintahan. Pembangunan Sistem Hukum Nasonal ini melahirkan konsep Proses Penyatuatapan Peradilan Agama. UndangUndang Nomor 14 Tahun 1970 tentang Ketentuan-ketentuan Pokok Kekuasaan Kehakiman yang telah menetapkan adanya 4 lingkungan peradilan, telah diubah dengan Undang-Undang Nomor 35 Tahun 1999. Dalam undang-undang ini diletakkan kebijakan bahwa segala urusan mengenai peradilan baik yang menyangkut teknis yudisial maupu urusan administrasi, dan finansial berada di bawah satu atap di bawah kekuasaan Mahkamah Agung. Kebijakan ini harus dilaksanakan paling lambat 5 (lima) tahun sejak diundangkannya pada tanggal 30 Juni 1999, akan tetapi dalam konsiderannya dikatakan bahwa mengingat sejarah Peradilan Agama yang spesifik dalam sistem peradilan nasional, pembinaan terhadap badan Peradilan Agama dilakukan dengan memperhatikan saran dan pendapat Menteri Agama dan Majelis Ulama Indonesia. ${ }^{21}$

5. Hal yang tidak kalah penting ialah pergumulan di sekitar Undang-Undang Nomor 3 Tahun 2006 dan Undang-Undang Per-

20 Ibid. hlm. xvii.

21 Abdul Gani Abdullah, Himpunan Peraturan Perundang-undangan tentang Penyatuatapan Peradilan Agama ke Mahkamah Agung (Jakarta: Ditjen Badan Peradilan Agama. 2004), hlm. 22. bankan Syari'ah Nomor 21 Tahun 2008, baik sebelum disahkan (sebagai RUU) maupun sesudah disahkan.

Kajian filosofis yuridis terhadap RUU Perbankan Syari'ah menunjukkan bahwa perkembangan kebutuhan hukum masyarakat (muslim khususnya) terhadap kesadaran menjalankan syariat Islam sebagai konsekuensi dari keyakinanya semakin tinggi, Ini berarti bahwa pluralisme hukum harus diterima sebagai realitas (real of entity) yang majemuk (legal plurality) dalam kehidupan bermasyarakat, yang diungkapkan oleh Cottenel (1995) sebagaimana dikutip oleh M. Ali Mansyur mengatakan bahwa: "We should think of law as a phenomenon pluralistically, as a regulation of many krud existing in a veriety of relationships. same qf the quit tenuous, with the primary legal institutions of the centralized state". ${ }^{22}$

Eksistensi Undang-Undang Nomor 3 Tahun 2006 tentang Peradilan Agama, Undang-Undang Perkawinan Nomor 1 Tahun 1974, Undang-Undang Nomor 38 Tahun 1999 tentang Pengelolaan Zakat, Instruksi Presiden Nomor 1 Tahun 1991 Tentang Kompilasi Hukum Islam (KHI) dan sekarang Rencana Undang-Undang Perbankan Syari'ah (telah disahkan bulan Juli 2008), tidak dapat dilepaskan dari historis (sejarah), artinya lahirnya institusi di atas bukan institusi yang "ahistoris" melainkan "historisch bepaald". Artinya munculnya dinamika hukum tersebut tidak dapat melepaskan/menyembunyikan dinamika sosial di belakangnya.

Hukum tumbuh, berkembang dan ambruk disebabkan oleh dinamika dalam masyarakat. Polarisasi kewenangan Pengadilan Agama mengadili perkara sengketa perbankan syari'ah/perbankan Islam, yang dalam draft Rencana Undang-Undang (RUU) Perbankan Syari'ah terutama pada Pasal 52 yang menyatakan bahwa penyelesaian sengketa pada perbankan syari'ah dilakukan oleh pengadilan umum. Dalam penjelasan dinya-

22 M. Ali Mansyur, Aspek Filosofis, Yuridis dan Sosiologis Penyelesaian Segketa Ekonomi Syari'ah dalam Seminar Nasional (Semarang: Kerjasama UNISSULA, PTA Semarang dan MUI Jawa Tengah) tanggal 19 Maret 2008, hlm. 2. 
takan bahwa penyelesaian sengketa pada perbankan syariah dilakukan pengadilan umum karena transaksi terkait dengan perbankan syari'ah bersifat komersial. Sebelum penyelesaian sengketa diserahkan kepada pengadilan umum dapat dilakukan upaya-upaya sebagai berikut:

1. Melalui musyawarah; dan

2. Dalam hal musyawarah sebagaimana dimaksud pada huruf a tidak mencapai kesepakatan, maka penyelesaian sengketa dapat dilakukan melalui mediasi perbankan atau mekanisme arbitrase syariah.

Pemahaman hukum yang demikian jika dilihat dari aspek filosofis yuridis pada dasarnya tidak menjawab kebutuhan rasa keadilan Umat Islam sebagai konsekuensi pluralisme hukum yang hidup dan tumbuh. Karenanya penyerahan ke Pengadilan Umum/Pengadilan Negeri dirasa kurang memenuhi rasa keadilan (contradictoris value) dan bertentangan dengan prinsip "historical bepaald" yang telah terjadi selama ini. Karena itu penyelesaian sengketa perkara perbankan Islam harus diserahan kepada Pengadilan Agama.

Mencermati keberadaan Peradilan Agama, secara yuridis normatif merupakan amanat konstitusi Undang-Undang Dasar Negara Kesatuan RI 1945 Pasal 24, 25, yang konkritisasi formalitasnya Undang-Undang Nomor 3 tahun 2006 dan dipayungi oleh Undang-Undang Nomor 4 Tahun 2004 mengenai Kekuasaan Kehakiman, maka Pasal 52 Rancangan Undang-Undang Perbankan Syari'ah, yang inti pokoknya sebagaimana diuraikan di atas jika diteropong memberikan kepastian hukum. Untuk mewujudkan kepastian hukum unsur penegakan hukum dari Friedman (substansi, struktur dan kultur) penekanan unsur manusia merupakan pelaku utama dalam segala kegiatan untuk mewujudkan keadilan (the legal system is not a machine; it is run hy human beings). ${ }^{23}$

Karena itu untuk mewujudkan keadilan, pendekatan hukum yang bersifal empirik-

23 Lawrence Meir Friedman sebagaimana dikutip oleh Ahmad Ali menjelaskan tiga unsur sistem hukum, yaitu struktur (structure), substansi (substance), dan kultur hukum (legal culture). Ahmad Ali, Keterpurukan Hukum Di Indonesia (Jakarta: Ghalia Indonesia. 2002), hlm. 7. positivistik tidak cukup, tetapi proses interaksi antara manusia dengan lingkungan yang dilandasi oleh budaya akan menjadi lebih bermakna. Dalam hal ini maka pemahaman hukum melalui pengalaman internal para subjek pelaku dan hukum merupakan makna simbolik yang termanifestasikan oleh para pelaku sosial yang tampak dalam interaksi antar mereka. Berdasarkan pemahaman (verstehen) dan interpretasi, dapat difahami bahwa makna nilai-nilai di balik perilaku hukum. Karenanya kajian yang digunakan bukan lagi semata-mata yuridis-normatif melainkan pendekatan socio legal-antro.

Memperhatikan paradigma berfikir yang menyamaratakan penyelesaian sengketa Perbankan Syari'ah dengan non-syari'ah dapat mengakibatkan hukum menjadi disorder of law, karena kompetensi absolut ekonomi syariah berada di Pengadilan Agama beserta perangkat hukumnya, yang sarat dengan nilai, asas dan ide serta tujuan yang sudah jelas. Jika kemudian penerapannya tidak pas, artinya tidak berasal atau ditumbuhkan dari kandungan masyarakat akan merupakan masalah, maka hal tersebut akan melahirkan terjadinya ketidakcocokan antara nilai-nilai yang menjadi pendukung sistem hukum yang bersangkutan dengan nilai-nilai yang dihayati oleh anggota masyarakat itu sendiri.

Berkenaan dengan hal tersebut di atas, maka penyelesaian sengketa ekonomi syari'ah oleh Pengadilan Negeri bertentangan dengan pemahaman hukum yuridis, sosiologis, dan antropologis. Alasan yuridis disebabkan bertentangan dengan UUPA No. 3 Tahun 2006. Alasan sosiologis karena mengabaikan kepentingan sosial umat Islam. Sedangkan alasan antropologis karena mengabaikan perilaku ekonomi umat Islam yang berpegang kepada ketentuan hukum syariat.

Berdasarkan uraian di atas, penulis merumuskan beberapa pokok pikiran sebagai berikut: Pertama, penguatan Peradilan Agama pada masa reformasi tampaknya semakin mendorong kelembagaan Peradilan Agama menjadi satu atap di bawah naungan Mahkamah Agung dan sejajar dengan peradilan lainnya; Kedua, untuk meningkatkan peran dan fungsi aparatur penegak hukum pada 
Peradilan Agama, pembinaan yang dilakukan oleh Mahkamah Agung bukan hanya dari segi peningkatan kualitas sumber daya manusia, namun juga dari segi pengembangan organisasi, kelembagaan, dan sarana prasarana. Jika sebelumnya Peradilan Agama dianggap terbelakang, di era reformasi menjadi sejajar dengan Peradilan Negeri; dan Ketiga, memasuki fase era reformasi, kewenangan Peradilan Agama diperluas untuk menyelesaikan sengketa ekonomi syari'ah sebagaimana diatur dalam Pasal 49 UndangUndang Nomor 3 Tahun 2006.

\section{Peranan Peradilan Agama dalam Pem- bentukan Tata Hukum Nasional}

Peranan berasal dari kata "peran", dalam bahasa Inggris terjemahnya "role". Suatu peran terkait dengan eksistensi. Peran Peradilan Agama terkait dengan apa kedudukan, tugas pokok Peradilan Agama, apa fungsinya dan bagaimana kiprah Peradilan Agama sebagai suatu sub sistem dari sistem hukum nasional. Oleh karena itu, keberadaan Peradilan Agama sebagai suatu pelaksanaan syariat Islam menjadi suatu keniscayaan.

Hukum-hukum Allah terdapat dalam alQuran dan Hadits. Hukum-hukum itu qath'î al-dalâlah, abadi sifatnya, transendental, dan universal. Hukum-hukum yang universal seringkali disebut sebagai syariat dalam arti luas, sedangkan hukum-hukum Allah dalam arti sempit disebut sebagai figh. Hukumhukum fiqh sifatnya zhannî al-dalâlah, dan penerapannya terbatas pada tempat, ruang, dan waktu.

Aktualisasi figh yang yang terbatas dengan ruang dan waktu menjadikan banyaknya pendapat-pendapat yang datang dari ahli figh. Bervariasinya pendapat ahli fiqh menjadikan figh sebagai hukum diyani, yakni masyarakat cenderung kepada hubungan manusia dengan Khaliknya saja. Berbeda dengan hukum diyani, figh bisa menjadi hukum wadl'i bilamana ia mempunyai kekuatan daya paksa pemberlakuannya dan ada sanksi yang mengancamnya. Dalam konteks inilah relasi syari'ah, figh, dan perubahan sosial perlu mendapat kajian yang mendalam. Hal ini disebabkan, di satu sisi keberadaan Peradilan Agama merupakan wujud penerapan syariat Islam, sedangkan di sisi lain merupakan bagian dari sistem tata hukum nasional. Dalam tata hukum Indonesia dikenal sumber hukum dasar nasional sebagai filosofis gronsdlag adalah Pancasila sebagaimana yang tertulis dalam Pembukaan UndangUndang Dasar 1945.

Masuknya figh ke dalam tatanan hukum Indonesia (hukum positip), dari segi penafsiran bahwa dasar negara Pancasila merupakan ijma' jama'i ulama Indonesia bahwa syariat (baca: dinul Islam) tidak boleh dipisahkan dari negara dan begitu juga negara harus mengurus masalah agama. Hal ini jelas tercantum dalam Sila I Pancasila dan Pasal 29 UUD 1945. Selanjutnya, bagaimana proses produk pemikiran hukum Islam yang ada dalam kitab-kitab figh menjadi produk pemikiran berupa undang-undang adalah suatu proses perubahan masyarakat yang masuk dalam kajian sosiologi hukum dan hukum murni sebagaimana teori Hans Kelsen yang menyatakan bahwa hukum adalah suatu metode yang khusus untuk mengontrol perilaku manusia dengan alat pemaksa. Teori hukumnya meliputi lapisan bertingkat/hierarki (stueffentheorie) norma-norma hukum Internasional dan norma dasar (groundnorm). ${ }^{24}$

Sesuai dengan teori tersebut, penulis berpendapat bahwa bahwa Pancasila merupakan dasar filososfi negara; sedangkan Undang-Undang Dasar 1945 sebagai aturan hukum dasar; Ketetapan Majelis Permusyawaratan Rakyat Republik Indonesia sebagai norma hukum; Peraturan Pemerintah, dan peraturan-peraturan di bawahnya sebagai nilai praksis dan nilai instrumental tata hukum di Indonesia. Hal ini didasarkan kepada Tata Urutan Perundang-Undangan yang ada dalam TAP MPR Nomor: III/MPR/2000 Pasal 3 yaitu:

1. Undang-Undang Dasar 1945;

2. Ketetapan Majelis Permusyawaratan Rakyat Republik Indonesia;

3. Undang-Undang;

4. Peraturan Pemerintah Pengganti UndangUndang (Perpu);

24 http://mhusnimubaroq.blogs.friendster.com/2007/05/autobigrafi, diakses tanggal 25 April 2014. 
5. Peraturan Pemerintah;

6. Keputusan Presiden; dan

7. Peraturan Daerah.

Interpretasi Pancasila sebagai nilai dasar (basic value, filosofis gronsdlag) mengandung pengertian bahwa Islam mengadopsi syari'ah yang termaktub dalam al-Quran dan hadits sebagai wahyu diterjemahkan ke dalam teori-teori bagaimana hubungan Islam dan negara. Beberapa pakar hukum Islam mempertanyakan apakah Islam sebagai negara, ataukah Islam sebagai khilafah atau Islam sebagai al-daulah. Konsep ini mengacu kepada pemahaman bahwa ketika Rasulullah SAW melaksanakan misi dakwah dalam sebuah masyarakat madani, berperan sekaligus yakni sebagai spiritual and political power.

Dalam pandangan Ibnu Taymiyah ${ }^{25}$ negara dan agama saling berhubungan, tanpa kekuasaan negara yang bersifat memaksa agama berada dalam bahaya. Tanpa disiplin hukum wahyu, negara pasti menjadi sebuah organisasi yang tirani. Pendapat Ibnu Taymiyah tersebut kemudian dipertegas pula pemikir muslim lainnya yaitu oleh Ibnu Khaldûn, ${ }^{26}$ yang mengatakan bahwa organi-

25 Ibnu Taymiyyah, dalam karyanya al-Siyâsat alSyar'iyyah telah menjelaskan gagasan Ahl al-Syawkah sebagai ganti teori Ahl al-Hall wa al-'Aqd (lembaga pemberhentian dan pengangkatan kepala negara) dalam sistem khilafah, Ibn Taymiyyah menegaskan, seorang penguasa apa pun namanya baik amir, malik, atau sultan, harus ada semacam ikatan emosional dan politik antara dirinya dengan rakyat. Karena, yang bersangkutan tanpa dukungan rakyat melalui orang-orang yang berpengaruh atas mereka (ahl al-Syawkah) tidak akan pernah jadi pemimpin (penguasa). Jika ikatan emosional itu lepas, maka legitimasi politiknya pun akan lepas dan yang bersangkutan akan jatuh. Oleh sebab itu, menurut Ibnu Taymiyyah, ikatan emosional dan politik harus tetap dijaga melalui tindakan yang mencerminkan pengejawantahan ikatan emosional dan politik itu dan menempatkan dirinya seakan-akan orang yang disewa oleh rakyat melalui ahl al-Syawkah tersebut. Taqiy al-Dîn Ibn Taymiyyah, al-Siyâsat alSyar'iyyah fî Ishlah al-Ra'i wa al-Ra'yaț, (Mesir: Dâr alKitâb al-'Arabî. 1979), cet. IV, hlm. 162 dan Taqiy al-Dîn Ibn Taymiyyah, Majmu' Fatawâ Syaykh al-Islâm Ahmad Ibn Taymiyyah (Rabat: t.pn. 1981), hlm. 266.

${ }^{26}$ Ibnu Khaldun, dalam karyanya Muqaddimah menjelaskan bahwa kepemimpinan adalah sunnatullah. Runtuh dan kokohnya suatu kekuasaan sangat bergantung pada ashabiyyah (solidaritas sosial). Konsep ashobiyah ini menyiratkan perlunya ruang bagi konflik kepentingan antar penguasa dan yang dikuasai sehingga kedua belah pihak saling memiliki posisi tawar-me- sasi kemasyarakatan suatu kemestian bagi manusia. Tanpa itu eksistensi mereka tidak akan sempurna, sebagaimana kehendak Allah menjadikan mereka sebagai khalîfahNya untuk memakmurkan bumi.

Tiga bentuk paradigma tentang hubungan agama dan negara, yakni: pendapat pertama, diwakili oleh kalangan Syi'ah yang mengatakan bahwa negara merupakan lembaga politik dan keagamaan sekaligus; pendapat kedua diwakili oleh kalangan Sunni, kelompok ini lebih menekankan ijma' (konsesus) dan bai'at (pembai'atan) kepada kepala negara; dan pendapat ketiga diwakili oleh paradigma pemikiran kaum sekuleristik yang menolak pendasaran agama pada negara, atau paling tidak menolak determinasi Islam akan bentuk tertentu pada negara. $\mathrm{Na}$ mun demikian, baik al-Quran maupun sunnah tidak memiliki preferensi terhadap sistem politik yang mapan untuk menetukan bentuk legal-formal negara yang ideal. Islam hanya memiliki seperangkat nilai etis yang dapat dijadikan rujukan dalam penyelenggaraan negara yang sejalan dengan prinsip-prinsip demokrasi.

Dalam teori Imâmah, Ayatullah Khomeini dikenal sebagai tokoh utama gerakan Revolusi Islam Iran pada tahun 1979. Menurut Ayatullah Khomeini, hakikat manusia adalah sebagai makhluk Allah. Kedudukan manusia di muka bumi memilk hak dan kewajiban sebagai khalifah. Dalam ketatanegaraan Islam, Imam Khomeini menjelaskan konsep pembagian kekuasaan negara melalui konsep Imâmah, di mana Dewan Imâmah menjadi pemegang otoritas tertinggi dalam negara konstitusional Syi'ah modern. Imâmah merupakan inti dari konsep wilâyat al-Fiqîh yang menekankan otoritas Allah kepada Rasul-Nya (Muhammad SAW) diteruskan oleh adanya para imam yang faqih, kekuasaannya bersifat hierarkis (berupa marja'-marja'), dan sekali-

nawar untuk mencapai kepentingan yang saling menguntungkan. Mahmoud Rabi'. The political theory of Ibn Khaldun (Leiden: E.J. Brill. 1967) dan Ibn Khaldun. The Muqaddimah: An Introduction to History, translated from the Arabic by Franz Rosenthal (New York: Princeton University Press. 1958) dikutip dari http://en.wikipedia.org/wiki/ IbnKhaldun, diakses tanggal 25 Januari 2014. 
gus merupakan kumpulan subyek yang terpilih. Dalam konteks politik Syi'ah, konsep pemisahan kekuasaan diatur dalam bingkai demokrasi dan konstitusi republik Islam berdasarkan pola hubungan Imâmah dan 'Ummah. Imâmah adalah representasi kekuasaan Allah, sedangkan ummah adalah representasi dari kekuasaan manusia untuk mengatur dirinya sendiri. Aplikasi teori ini tampak pada model pemerintahan presidential Republik Islam Iran di mana konstitusi Iran mengatur lembaga eksekutif ada pada presiden, legisltif berada di parlemen dan yudikatif ada pada pengadilan. Namun lembaga tertinggi tetap berada di tangan Dewan Faqih. ${ }^{27}$

Demikian pula di kalangan Sunni, dikenal nama tokoh Abû Hassan al-Mâwardî merupakan tokoh pemikir di abad pertengahan yang memper-kenalkan prinsip-prinsip ketatanegaraan berdasarkan kepada khilâfah alIslâmiyyah. Dalam kitabnya, al-Ahkam alSulthâniyyah, al-Mâwardî menjelaskan konsep negara dan kekuasaan berpijak pada kekuasaan Allah yang diwakili oleh Khalifah. Khalifah menurutnya representasi kekuasaan Allah. Oleh karena itu, otoritas khalifah setara dengan otoritas ketuhanan. Namun dalam hal pemenuhan hak dan kewajiban penguasa (khalifah) dan rakyatnya ('ummah) dijembatani oleh adanya penasehat khalifah (wazîr) dan wakil rakyat (ahl al-hal wa al-'aqd dan majelis syura') dalam sistem ketatanegaraan Islam. Menurutnya, pola pemisahan kekuasaan disepakati melalui ijma' (consensus) antara ketiga elemen kekuasaan politik itu sehingga tidak ada tarik-menarik politik dalam proses pengambilan keputusan. ${ }^{28}$

27 Konsep pemisahan kekuasaan antara legislatif, eksekutif dan yudikatif diatur dalam bingkai demokrasi dan konstitusi republik Islam berdasarkan pola hubungan Imâmah dan 'Ummah. Lihat pejelasan Ali Shariati, 'Ummah dan Imâmah (Jakarta: Bulan Bintang. 1991) yang telah mendeskripsikan pengalaman sistem politik Republik Islam Iran dan lihat pula Ayatullah Khomeini, Human Rights in Islam (Teheran: Teheran University Press. 1980) hlm. 1-2.

28 Al-Mâwardî, al-Ahkâm al-Sulthâniyyah (Beirut: Dâr al-Fikr. 1967), hlm. 5. Teori khilafah dapat dilihat pula dalam Abû Ya'la al-Farrâ', al-Ahkâm al-Shulthâniyyah (Beirut: Dâr al-Fikr. t.th.), hlm. 19, Ibnu Taymiyyah, al-Siyâsat al-Syar'iyyat (Beirut: Dâr al-Kutûb al'Arabiyah. 1966), hlm. 161, Imâm al-Ghazâlî, al-lqtishâd fî al-l'tiqâd (Beirut: Dâr al-Fikr. 1976), hlm. 97, Imâm al-
Sejalan dengan pendapat al-Mâwardî tentang paham teodemokrasi, bukan teokrasi atau sekularistik, maka Peradilan Agama sebagai sebuah institusi, peran dan kedudukannya dalam negara Indonesia dapat direfleksikan dari Sila Pertama Pancasila: Ketuhanan yang Maha Esa dan norma-norma hukum di bawahnya. Ketentuan Pasal 29 ayat (1) dengan tegas menyatakan bahwa Negara berdasar atas Ketuhanan Yang Maha Esa, pada dasarnya mengandung tiga makna, yaitu:

1. Negara tidak boleh membuat peraturan perundang-undangan atau melakukan kebijakan-kebijakan yang bertentangan dengan dasar keimanan kepada Tuhan Yang Maha Esa;

2. Negara berkewajiban membuat peraturan perundang-undangan atau melakukan kebijakan-kebijakan bagi pelaksanaan wujud rasa keimanan kepada Tuhan Yang Maha Esa dari segolongan pemeluk agama yang memerlukannya; dan

3. Negara berkewajiban membuat berbagai peraturan perundang-undangan yang melarang siapapun melakukan pelecehan terhadap ajaran agama (paham atheisme).

Menurut Jimly Ash-Shiddiqie, ${ }^{29}$ Prinsip Ketuhanan Yang Maha Esa diwujudkan melalui prinsip hirarki norma dan elaborasi norma. Dalam konteks sistem hirarki norma, perlu dibedakan antara pengertian syariat dengan figh dan dengan qanun. Menurut logika sistem hirarki itu, maka dalam prinsip pertama, hukum suatu negara berisi normanorma yang tidak boleh bertentangan dengan norma yang terkandung dalam syariat agama-agama yang dianut oleh warga masyarakat. Sedangkan dalam prinsip yang kedua, norma-norma yang tercermin dalam rumusan-rumusan hukum negara, haruslah merupakan penjabaran atau elaborasi nor-

Qurthubî, Tafsîr al-Qurthubî (Beirut: Dâr al-Kutûb al'Arabiyyah, t.th.), juz I, hlm. 264, dan 'Abdurrahman 'Abdul Khaliq, al-Syurâ (Beirut: Dâr al-Kutûb al'Arabiyyah. t.th.), hlm. 26.

29 Jimly Asshiddiqie, Pembangunan Sistem Hukum Nasional: Hukum Islam dan Integrasi Pendidikan Hukum, Orasi Ilmiah Dies Natalis ke-39 UIN Sunan Gunung Djati Bandung, pada tanggal 9 April 2007. 
matif ajaran-ajaran syariat agama yang diyakini oleh warga negara.

Terkait dengan diakuinya Peradilan Agama sebagai salah satu kekuasaan kehakiman dalam UUD 1945 Pasal 24 A (amandemen keempat), maka keberlakuan syariat Islam merupakan suatu keniscayaan. Dengan demikian keberadaan Peradilan Agama dalam pelaksanaan syariat Islam di Indonesia dan juga sebagai sebuah institusi tata hukum Indonesia, semakin nyata dalam sistem peradilan nasional di Indonesia. Di antara produk perundangan-undangan lain yang bersifat mengatur ialah Undang-Undang Nomor 41 Tahun 2004 tentang Wakaf, Undang-Undang Nomor 3 Tahun 2006 Undang-Undang Nomor 17 tahun 1999 tentang Haji dan lain-lain.

Peranan Peradilan Agama sebagai sebuah pranata yang ikut mewarnai politik hukum, sebagaimana dikatakan Muladi bahwa dalam pengertian umum, politik hukum merupakan bagian integral dari kebijakan sosial (social policy) di bidang hukum dan merupakan pilihan dalam rangka menciptakan rasa tertib dan rasa aman dalam kehidupan sosial. ${ }^{30}$

Politik hukum merupakan sebuah legal policy, yang akan atau telah dilaksanakan secara nasional oleh pemerintah Indonesia yang meliputi: Pertama, pembangunan hukum yang berintikan pembuatan dan pembaruan terhadap materi-materi hukum agar sesuai dengan kebutuhan; dan Kedua, pelaksanaan ketentuan hukum yang telah ada, termasuk penegasan fungsi lembaga dan pembinaan para penegak hukum.

Menurut Mahfud, ${ }^{31}$ politik hukum mencakup proses pembuatan dan pelaksanaan hukum yang dapat menunjukan sifat dan kearah mana hukum akan dibangun dan ditegakkan. Sedangkan menurut Muladi, ${ }^{32}$ politik hukum yang sarat akan interaksi politik dan hukum, akan mencakup: politik pembentuk-

30 Muladi, Interaksi antara politik dan hukum, dalam www.compani. com//artikel//html, diakses tanggal 18 September 2009.

31 Moh. Mahfud MD, Politik Hukum di Indonesia (Jakarta: LP3S. 1998), hlm. 68.

32 Muladi, Interaksi antara politik dan hukum, kutipan artikel yang dipublikasikan dalam www.compani.com//artikel//html, diakses tanggal 29 Juni 2010. an hukum (law making policy); politik penegakan hukum (law enforcement policy); dan politik pembudayaan hukum (law awareness policy). Ketiga hal tersebut mencerminkan hakekat sistem hukum yang mencakup struktur, substansi dan kultur hukum.

Hubungan konfigurasi politik terhadap produk hukum sangat signifikan. Keduanya menunjukan kausalitas dengan derajat determinasi yang menunjukan pada tiga kondisi. Pertama, hukum determinan atas politik. Artinya kegiatan-kegiatan politik diatur oleh hukum; Kedua, politik determinan atas hukum, karena hukum merupakan hasil atau kristalisasi dari kehendak-kehendak politik yang saling berinteraksi dan (bahkan) saling bersaingan; dan Ketiga, politik dan hukum sebagai subsistem kemasyarakatan yang berada pada posisi yang derajat determinasinya seimbang antara satu dengan yang lainnya.

Studi ini bermuara pada asumsi bahwa ketika terjadi konvergensi antara politik dan hukum, maka hukumlah yang terpengaruh oleh politik. Hal ini disebabkan, sub sistem politik memiliki konsentrasi energi yang lebih besar daripada hukum. Daniel S. Lev ${ }^{33}$ dalam penelitiannya tentang Peradilan Agama di Indonesia menyatakan bahwa bahwa lembaga-lembaga hukum tidaklah dapat dipahami tanpa mengaitkan pertumbuhannya dengan politik.

Selanjutnya, produk hukum berkisar pada dua karakter: responsif dan konservatif. Produk hukum responsif - disebut pula populistik - adalah produk hukum yang mencerminkan rasa keadilan dan memenuhi harapan masyarakat. Dalam proses pembuatannya, memberikan peranan besar dan partisipasi penuh kelompok-kelompok sosial atau individu di dalam masyarakat. Hasilnya bersifat responsif terhadap tuntutantuntutan kelompok sosial atau individu dalam masyarakat. Teori yang paling tepat untuk menggambarkan eksistensi Peradilan Agama di Indonesia sebagai hasil dari perubahan sosial adalah didasarkan kepada teori

33 Daniel S.Lev, Islamic Court in Indonesia, alih basa Zaini Ahmad Noeh, Peradilan Agama Islam di Indonesia Suatu Studi tentang Landasan Politik Lembaga-lembaga Hukum (Jakarta: PT. Intermasa. 1980), hlm. 15. 
perubahan hukum yang dikemukakan oleh Rosque Pound. ${ }^{34}$ Pound menjelaskan bahwa hukum dapat diperankan sebagai alat untuk mengubah masyarakat (law as a tool of social engeneering). Hukum-hukum yang dibuat oleh kekuasaan dapat berakibat langsung atau tidak langsung terhadap perubahan sosial di masyarakat. ${ }^{35}$ Menurut Pound dan Eugen Ehrilich, yang mengatakan bahwa hukum yang baik adalah hukum yang sesuai dengan hukum yang hidup di dalam masyarakat. ${ }^{36}$ Selain itu, hukum dapat juga digunakan oleh penguasa sebagai alat pembangunan. ${ }^{37}$ Sebagai contoh adalah adanya UU Nomor 1 Tahun 1974 tentang Perkawinan dan UU Nomor 7 Tahun 1989 jo tentang Peradilan Agama yang kemudian diamandemen menjadi UU Nomor 3 Tahun 2006jo dan kini UU Nomor 50 Tahun 2009 merupakan sebagian indikator bahwa kebijakan politik hukum di Indonesia telah berpengaruh positif, baik secara langsung maupun tidak langsung terhadap pengakuan hakim perempuan di Peradilan Agama.

Produk hukum konservatif disebut pula ortodoks - adalah produk hukum yang isinya lebih mencerminkan visi sosial elit politik, lebih mencerminkan elit pemerintah, bersifat positif instrumentalis - yakni menjadi alat pelaksanaan ideologi dan program negara. Hal ini sejalan dengan teori legisme Han Kelsen ${ }^{38}$ yang mengatakan bahwa hukum itu harus dibersihkan dari anasir-anasir yang tidak yuridis seperti etis, sosiologis dan politis. Sehing-

34 Rosque Pound, The Law Theory of Social Engeneering, dalam Tom Cambell, Tujuh Teori Sosial: Sketsa, Penilaian dan Perbandingan (Yogyakarta: Kanisius. 1994), hlm. 13.

35 Ibid. hlm. 107. Lihat juga Satjipto Rahardjo, Hukum dan Masyarakat (Bandung: Angkasa. 1980), hlm. 112 .

36 Rosque Pound, The Law Theory of Social Engeneering, dalam Tom Cambell, Tujuh Teori Sosial: Sketsa, Penilaian dan Perbandingan (Yogyakarta: Kanisius. 1994), hlm. 13. Bandingkan dengan Satjipto Rahardjo, Hukum dan Masyarakat (Bandung: Angkasa. 1980), hlm. 112.

37 A. A. G Peters dan Koesriani Siswosubroto, Hukum dan Perkembangan Sosial. hlm. 207.

38 Hans Kelsen dikenal sebagai salah seorang pemikir Barat keturunan Yahudi dari Austria pada abad ke-17 yang juga banyak menjelaskan tentang teori hukum positif (legal positivism theory), khususnya tentang teori hukum norma dasar (groundnorm) dan konstitusi (constitution). ga dalam hukum positip (hukum tertulis yang dibuat penguasa) berlaku postulat "hukum tanpa kekuasaan adalah angan-angan, sedangkan kekuasaan tanpa hukum adalah kedzaliman".

Teori hukum Hans Kelsen sangat dipengaruhi oleh ajaran hukum murni (natural law) Thomas Hobbes. Ajaran hukum murni (natural law) dibagi dua golongan yakni aliran hukum positif (legal positivism theory) dan aliran hukum realis (legal realism theory). Legal Positivism Theory diperkenalkan oleh H.A.L. Hart yang menyatakan bahwa (1) hukum adalah fakta-fakta sosial (social facts) yang terdiri dari pene-gakan hukum, moralitas dan norma-norma sosial lainnya. (2) ukuran kepastian hukum hanya bisa digaransi oleh patokan moral (moral considerations). Menurut Kelsen, kedua poin tersebut dapat diaktualisasikan dalam bentuk norma dasar (groundnorm) pada konstitusi. Teori konstitusi ini kemudian dikembangkan oleh Adolf Merkel dan Carl Scmith (Madzhab Wina) yang menyatakan bahwa konstitusi adalah sistem hukum disusun secara hierarkies dan priramidal, bersifat universal dan sistematis, di mana hukum yang di bawah tidak boleh bertentangan dengan hukum yang lebih tinggi. ${ }^{39}$

Adapun Sir Henry Maine, tokoh sosiologi hukum lainnya, berpendapat bahwa perkembangan hukum berjalan dari status ke kontrak adalah sesuai dengan perkembangan dari masyarakat yang sederhana dan homogen ke masyarakat yang telah kompleks susunannya dan bersifat heterogen di mana hubungan antar manusia lebih ditekankan pada unsur pamrih. ${ }^{40}$ Sehingga kebijakan hukum akan diterima masyarakat apabila terjadi hubungan saling menguntungkan berdasarkan kegunaannya. Namun teori ini semata berdasarkan filsafat hukum utilitarianisme.

39 Hans Kelsen, Pure Theory of Law (Clark: Lawbook Exchange Ltd. 2005), Robert S. Summers, Instrumentalism and American Legal Theory (Ithaca, NY: Cornell University Press. 1982), David Lyons, Moral Aspects of Legal Theory (Cambridge: Cambridge University Press. 1993) dan Neil MacCormick, Legal Reasoning and Legal Theory (Oxford: Oxford University Press, 1979) dalam http://en.wikipedia.org/wiki/Jurisprudence.

40 Soerjono Soekanto, Pokok-pokok Sosiologi Hukum. hlm. 94. 
Teori lainnya diungkapkan oleh Pitirin Sorokin, yang menyatakan bahwa perubahan sosial dan perubahan hukum erat kaitannya dengan tahapan-tahapan sturktur sosial di masyarakat. Masyarakat berkembang sesuai dengan nilai-nilai tertentu yang sedang menonjol di dalam masyarakat bersangkutan. Nilai-nilai tersebut adalah yang ideational (kebenaran absolut sebagaimana diwahyukan oleh Tuhan), sensate (nilai-nilai yang didasarkan pada pengalaman), dan yang idealistic (yang merupakan kategori campuran). Hukum dan gejala-gejala sosial budaya lainnya terbentuk sesuai dengan bentuk nilai-nilai yang sedang berlaku di dalam masyarakat. ${ }^{41}$

Dalam konteks Indonesia, Hazairin dan Soepomo merupakan dua ahli hukum yang juga mendukung adanya hubungan perubahan hukum dan perubahan sosial. Menurut Hazairin ada hubungan antara hukum adat dan kesusilaan di masyarakat. Perubahan di antara keduanya saling mempengaruhi. Demikian pula menurut Soepomo ada hubungan antara hukum adat dan perubahan sosial terutama setelah kemerdekaan. ${ }^{42}$

Berkenaan dengan hal tersebut, penulis lebih mendukung teori perubahan hukum yang dikemukakan oleh Ibnu Qayyim alJawziyyah yang menjustifikasi eksistensi Peradilan Agama di Indonesia. Peradilan Agama dapat diterima sebagai wujud konkrit Peradilan Islam di Indonesia produk dari perubahan sosial dan perubahan hukum. Hal tersebut sesuai dengan bunyi kaidah hukum Islam yang menyatakan:

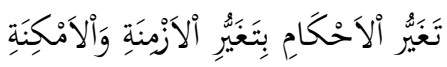

Berubahnya suatu hukum hendaknya disesuaikan dengan situasi, kondisi, waktu, dan tempatnya.

Dan merujuk kepada tujuan hukum Islam yang bersifat umum yaitu:

$$
\text { دفع المفاسد مقدم علئ جلب المصالح }
$$

Meniadakan kemadaratan dan mendahulukan kemaslahatan umum.

41 Ibid. hlm. 94-95.

42 Ibid. hlm. 97-98.
Kedua kaidah hukum tersebut menjadi pertimbangan untuk menjelaskan pola hubungan antara hukum dan masyarakat (waktu dan tempat) dengan tujuan kemaslahatan. Dengan demikian, penulis melihat perubahan regulasi tentang Peradilan Agama lahir akibat perubahan sosial dan perubahan hukum di masyarakat.

\section{E. Penutup}

Berdasarkan uraian di atas, penulis dapat manarik kesimpulan dari beberapa pokok pikiran sebagai berikut:

Pertama, perubahan hukum dan perubahan sosial adalah suatu fenomena yang saling mempengaruhi satu dengan lainnya. Perubahan dalam suatu hukum dapat berpengaruh terhadap perubahan di masyarakat. Demikian pula sebaliknya, perubahan masyarakat tampaknya dapat membawa perubahan pada hukum;

Kedua, menurut teori perubahan hukum Peradilan Agama di Indonesia yang dilihat dari segi kewenangan dan tugasnya yang diatur dalam tata hukum Indonesia dapat dipandang sebagai wujud konkrit Peradilan Islam; dan

Ketiga, menurut teori perubahan sosial dan hukum, segala bentuk pengambilan keputusan hukum di Peradilan Agama hendaknya bertujuan kemaslahatan dan mempertimbangkan politik hukum di masyarakat.

\section{Daftar Pustaka}

Abdullah, Abdul Gani. 2001. Peradilan Agama dalam Wadah Negara Pancasila (Dialog tentang RUUPA). Jakarta: PT. Logos Wacana Ilmu.

Abdullah, Abdul Gani. 2004. Himpunan Peraturan Perundang-undangan tentang Penyatuatapan Peradilan Agama ke Mahkamah Agung. Jakarta: Ditjen Badan Peradilan Agama.

Ali, Ahmad. 2002. Keterpurukan Hukum di Indonesia. Jakarta: Ghalia Indonesia.

Ali, Mohammad Daud dan Habibah Daud. 1995. Lembaga-lembaga Islam di Indonesia. Jakarta: Rajawali Pers. 
Asshiddiqie, Jimly. 2007. Pembangunan Sistem Hukum Nasional: Hukum Islam dan Integrasi Pendidikan Hukum, Orasi IImiah Dies Natalis ke-39 UIN Sunan Gunung Djati Bandung, pada tanggal 9 April 2007.

Cambell, Tom. 1994. Tujuh Teori Sosial: Sketsa, Penilaian dan Perbandingan. Yogyakarta: Kanisius.

Cormick, Neil Mac. 1979. Legal Reasoning and Legal Theory. Oxford: Oxford University Press.

Departemen Agama RI. 2000. Peradilan Agama di Indonesia: Sejarah Perkembangan Lembaga dan Proses Pembentukan Undang-undangnya. Jakarta: Departemen Agama, Ditbinbapera.

Djazuli, A. 2003. Fiqh Siyasah: Implementasi Kemaslahatan Ummat dalam Ramburambu Syari'ah. Jakarta: Kencana Prenada Media Group.

Ghazâlî, Imâm al-. 1967. al-lqtishâd fî alI'tiqâd. Beirut: Dâr al-Fikr.

Gunaryo, Achmad. 2007. Pergumulan Politik dan Hukum Islam, Reposisi dari Peradilan "Pupuk Bawang" ke Peradilan Sesungguhnya. Semarang, Pustaka Pelajar.

Haryono, Anwar. 1968. Hukum Islam: Kekuasaan dan Keadilan. Jakarta: Bulan Bintang.

Hutagalung, Mura P. 1985. Hukum Islam dalam Era Pembangunan. Jakarta: In Hill Co.

Ichtiyanto. 1991. Pengembangan Teori Berlakunya Hukum Islam di Indonesia. Bandung: Rosda Karya.

Jawziyyah, Ibn Qayyim al-. t.th. I'lam alMuwaqqi'în 'an Rabb al'Âlamîn. Beirut: Dâr al-Fikr.

Kelsen, Hans. 2005. Pure Theory of Law. Clark: Lawbook Exchange Ltd.

Khaliq, 'Abdurrahman 'Abdul. t.th. al-Syurâ. Beirut: Dâr al-Kutûb al-'Arabiyyah.

Khomeini, Ayatullah. 1980. Human Rights in Islam. Teheran: Teheran University Press.
Lukito, Ratno. 2008. Hukum Sakral dan Hukum Sekuler. Jakarta: Pustaka Alpabet.

Lyons, David. 1993. Moral Aspects of Legal Theory. Cambridge: Cambridge University Press.

Mahmoud Rabi'. 1967. The political theory of Ibn Khaldun. Leiden: E.J. Brill.

Mâwardî, al-. 1967. al-Ahkâm al-Sulthâniyyah. Beirut: Dâr al-Fikr.

MD, Moh. Mahfud. 1988. Politik Hukum di Indonesia. Jakarta: LP3S.

Muladi. 2009. Interaksi antara politik dan hukum, dalam www.compani. com//artikel/html diakses tanggal 18 September 2009.

Noeh, Zaini Ahmad. 1980. Peradilan Agama Islam di Indonesia: Suatu Studi tentang Landasan Politik Lembaga-lembaga Hukum. Jakarta: PT. Intermasa.

Praja, Juhaya S. 1981. Hukum Islam di Indonesia. Bandung: Rosda Karya.

Qasim, 'Abd al-Raḩman 'Abd al-'Azîz al-. 1997. al-Islâm wa Taqnîn al-Ahkâm. Riyadl: Jami'ah Riyadl.

Qurthubî, Imâm al-. t.th. Tafsîr al-Qurthubî. Beirut: Dâr al-Kutûb al-'Arabiyyah.

Rahardjo, Satjipto. 1980. Hukum dan Masyarakat. Bandung: Angkasa.

Rasyidi, H. M. (Penerjemah). 1984. Persoalanpersoalan Filsafat (Jakarta: Bulan Bintang.

Rosenthal, Franz. 1958. The Muqaddimah: an Introduction to History. New York: Princeton University Press.

Shariati, Ali. 1991. Ummah dan Imâmah. Jakarta: Bulan Bintang.

Summers, Robert S. 1982. Instrumentalism and American Legal Theory. Ithaca, NY: Cornell University Press.

Taymiyyah, Ibnu. 1966. al-Siyâsat al-Syar'iyyat. Beirut: Dâr al-Kutûb al-‘Arabiyah.

Taymiyyah, Taqiy al-Dîn Ibn. 1979. al-Siyâsat al-Syar'iyyah fî Ishlah al-Ra'i wa al-Ra'yat. Mesir: Dâr al-Kitâb al-'Arabî.

Taymiyyah, Taqiy al-Dîn Ibn. 1981. Majmu' Fatawâ Syaykh al-Islâm Ahmad Ibn Taymiyyah. Rabat: t.pn. 